\title{
Hvordan anvender studerende forhandling i computerkonferencer i forbindelse med deres læring?
}

\author{
Fremlæggelse og diskussion af udvalgte resultater fra det empiriske \\ forskningsprojekt "Faglige diskussioner i computerkonferencer"
}

\section{Pernille Rattleff}

Lektor, cand.polit., ph.d.

Institut for pædagogisk psykologi

Danmarks Pædagogiske Universitet

rattleff@dpu.dk

http://www.dpu.dk

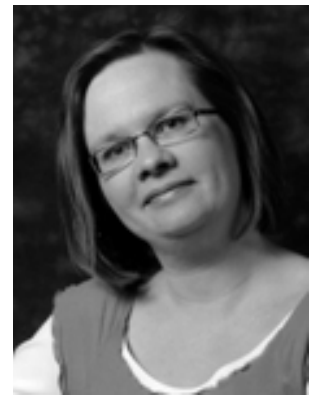

Pernille Rattleff (f. 1965) er uddannet cand.polit. og har en ph.d.-grad i IKT og lering fra Danmarks Pcedagogiske Universitet. Pernille har siden etableringen af Danmarks Pcedagogiske Universitet i 2000 være ansat ved universitetet, fra 2005 som lektor i evaluering ved Institut for pæedagogiske psykologi. Pernille Rattleff forsker i sammenhœengen mellem brug af IKT og læring i uddannelsessammenhæeng og på arbejdspladsen. Pernille har et systemteoretisk udgangspunkt med særlig vagt på det kommunikative aspekt af undervisning og på sammenhœengen mellem kommunikation, forhandling og laring. Pernille underviser - i blandt andet videnskabsteori og forskningsmetoder samt systemteori - på kandidatuddannelser ved Danmarks Pcedagogiske Universitet og på den tvœrinstitutionelle Master i IKT og Lœring. Pernille Rattleff deltager i forskningsprogrammet "Medier og IT i lceringsperspektiv" ved Danmarks Pcedagogiske Universitet.

\section{Indledning}

I litteraturen antages det (jf. eksempelvis Rattleff, 2005b, p. 197f), at der er mange - i hvert fald principielle - fordele ved at teknologistøtte undervisning, idet denne teknologistøtte antages at fremme studerendes leering. I litteraturen bemærkes det imidlertid desuden, at der i forbindelse med forskningen inden for feltet ikke er gjort meget for empirisk at undersøge læringen i forbindelse med teknologistøttet undervisning:

Little had as yet been done to establish rationales or procedures for evaluating the actual learning which takes place during a conference [computerkonference], especially when that learning is defined according to constructivist principles as the co-construction of knowledge by negotiation of meaning. (jf. eksempelvis Gunawardena et al., 1998, p. 2)

Men som Grue Sørensen bemærkede tilbage i 1974, så er læring tilsyneladende et vanskeligt begreb at få fastlagt:

At lære hører til pædagogikkens grundord og er et af de mest fundamentale begreber i alt, hvad der hedder undervisning og opdragelse [...] En klar og alment acceptabel definition af ordet lære har budt på store vanskeligheder. Der har vist 
sig det mærkværdige, at ordet i videnskabelig sprogbrug har antaget en langt videre betydning end i dagligdagssproget. (Grue-Sørensen, 1974, p. 197f)

Dette er muligvis en medvirkende årsag til, at empiriske undersøgelser af læring er vanskelige at gennemføre.

I projektet "Faglige diskussioner i computerkonferencer” undersøges det empirisk, hvordan teknologistøtte fremmer studerendes læring. Mere specifikt undersøges det, hvilken betydning studerendes forhandling ${ }^{1}$ har for studerendes læring. Med forhandling menes i denne sammenhæng forhandling i faglige diskussioner via skriftlig, asynkron, computermedieret kommunikation, som denne etableres i de såkaldte computerkonferencer ${ }^{2}$ - her computerkonferencen Virtual U (VU).

\section{Undersøgelsesfelt og forskningsspørgsmål}

Det er i flere sammenhænge empirisk godtgjort, at studerende har relativt få faglige diskussioner i computerkonferencer - jf. eksempelvis Benseman (1999) og Rattleff, (2001). På Masteruddannelsen i IKT og Læring (MIL) har underviserne på (blandt andet) modul 3 om "IKT og organisatoriske læreprocesser" imidlertid erfaring med, at de studerende har endog særdeles lange, faglige diskussioner. Det vil sige, at de skriver og poster indlæg i VU med studierelateret faglig information i modsætning til den ofte sete og mere udbredte studierelaterede praktisk-organisatoriske og ikke-studierelaterede, personlige information ${ }^{3}$.

Inspireret af den amerikanske psykolog og psykoterapeut George A. Kelly (Kelly, 1955; 1963) fastlægger Thomas og Harri-Augstein læring som: "The construction, reconstruction, negotiation and exchange of personally significant, relevant and viable meaning." (1985, p. xxiv). Forhandling antages således ikke alene at være af betydning for de studerendes læring, men i denne fastlæggelse - helt grundliggende - at være selve den kommunikative proces, hvorigennem den enkelte studerende lærer sig selv noget. Dette er i udmærket overensstemmelse med den tyske sociolog og systemteoretiker Niklas Luhmanns antagelse om, at erkendelse er en konstruktion (Luhmann, 1988), en antagelse i tråd med konstruktivistiske læringsprincipper (jf. det tidligere citat fra Gunawardena et al., 1998, p. 2), hvor: "[...] learning is defined according to constructivist principles as the co-construction of knowledge by negotiation of meaning."

Læring (det vil sige resultatet af læreprocessen) defineres af den svenske forsker Per-Erik Ellström som: "[...] relativt varaktiga förändringar hos en individ som et resultat av individens samspel med sin omgivning.” (Ellström, 1997, p. 67)

På baggrund af denne antagelse om, at læring (det vil sige relativt varige forandringer) kommer i stand via forhandling af mening, er udgangspunktet for den analyse, der gennemføres i projekt "faglige diskussioner i computerkonferencer", således den teoretisk begrundede formodning om, at forhandlingerne i de studerendes faglige diskussioner fører til den enkelte studerendes lering. I forlængelse af dette bliver spørgsmålet da: Hvordan kommer forhandling i stand?

I litteraturen findes nemlig flere empiriske studier af netop vanskelighederne ved forhandlinger i asynkrone medier (fx Bygholm \& Dirckinck-Holmfeld, 1997; DirckinckHolmfeld, 2002; Rattleff, 2003).

Der er således tale om to tilsyneladende modscetninger; for det første mellem de ikkeeksisterende (eller relativt begrænsede) faglige diskussioner i computerkonferencer blandt 
studerende i almindelighed og de faglige diskussioner, der kan iagttages blandt MILstuderende ${ }^{4}$. For det andet er der den tilsyneladende modsætning mellem litteraturens understregning af det vanskelige ved forhandling i asynkrone medier og de forhandlinger, der kan iagttages i de faglige diskussioner blandt MIL-studerende.

I forlængelse af disse tilsyneladende modsætninger formuleres følgende overordnede forskningsspørgsmål for forskningsprojekt "faglige diskussioner i computerkonferencer":

Hvilken betydning har forhandlingerne via den skriftlige, asynkrone, computermedierede, netudbredte kommunikation i computerkonferencerne $i$ Virtual $U$ for de studerendes lereproces i forbindelse med MILs modul 3?

Undersøgelsen er gennemført som en kombineret kvalitativ og kvantitativ undersøgelse. Indledningsvis gennemførte jeg et interview med udvalgte MIL-studerende. På baggrund af dette søgte jeg efterfølgende at kvantificere de fundne tendenser via en spørgeskemaundersøgelse med udsendelse af et elektronisk spørgeskema til samtlige MILstuderende, årgang 2005. Spørgeskemaet er designet på baggrund af det indledende interview med de udvalgte studerende. Spørgeskemaet er derefter pilottestet (på tre forskellige grupper af studerende) og tilrettet forud for næste pilottest.

\section{Tilrettelæggelse af undervisningen på MIL-modulet om "IKT og organisatoriske læreprocesser"}

For at bestå MIL's modul 3 om ’IKT og organisatoriske læreprocesser” (svarende til 7 ECTS points) skal de studerende i såkaldte kursusgrupper udarbejde en skriftlig opgave på maksimalt 15 normalsider om tilrettelæggelsen og gennemførelsen af en mindre empirisk undersøgelse af en problemstilling inden for modulets felt. Som optakt til gennemførelse af de studerendes empiriske undersøgelser afholdes for det første et seminar. For det andet er der en periode med litteraturstudier, hvor de studerende i kursusgrupperne på baggrund af modulets litteratur skal formulere et eller to diskussionsoplæg som input til den første online diskussionsperiode. For det tredje skal de studerende deltage aktivt i to online diskussionsperioder, der hver især foregår i én VU-konference. Den analyse, der følger nedenfor, er baseret på samtlige de VU-meddelelser, der blev skrevet og postet i den første online diskussionsperiode. Denne online diskussionsperiode var i efteråret 2005 tilrettelagt fra og med den 22. september til og med den 2. oktober. I denne første online diskussionsperiode var det et beståelseskrav, at de studerende som enkeltpersoner skrev og postede mindst 3 VU-meddelelser. Som kursusgrupper var de studerende desuden ansvarlige for, at hver kursusgruppe modererede og forestod opsamling på den VU-kommunikation, der var skrevet og postet i relation til den pågældende kursusgruppes oplæg til diskussion.

Velkomstmeddelelsen blev postet af en af modulets fire undervisere torsdag den 8. september 2005. Første egentlige indholdsmeddelelse blev postet af en studerende onsdag den 14. september 2005, og sidste egentlige indholdsmeddelelse blev postet af en studerende tirsdag den 4. oktober 2005.

\section{Computerkonferencekommunikationen i løbet af modulperioden}

I alt blev der i den første online diskussionsperiode postet 303 meddelelser i den ene konference, der var oprettet og dedikeret til denne online diskussionsperiode. To af disse meddelelser er postet af undervisere. Flere af de oprindelige 303 meddelelser er efterfølgende slettet af den pågældende forfatter. I alt er der slettet 27 meddelelser. Af de resterende 276 meddelelser er 2 forfattet af underviserne, mens de resterende 274 er forfattet af i alt 36 
studerende. De 274 meddelelser er fordelt på i alt 14 tråde - hvoraf 3 tråde kun består af en enkelt meddelelse.

De resterende 11 tråde (med flere end en enkelt meddelelse) har gennemsnitlig knap 25 meddelelser. Den længste tråd har 45 meddelelser.

Dette kan iagttages som et andet mønster end det typiske mønster for computerkonferencekommunikation. Om trådlængden skriver forskerne bag en amerikansk undersøgelse af computerkonferencekommunikationen i 1.571 tråde genereret i syv fjernuddannelsesforløb således: "Thus, most of the threads are short and contain, at most, a few exchanges. In fact, over $50 \%$ of the threads (the threads of size 1 ) are not even discussions in the conventional sense, since they only consist of a single entry.” (Hewitt \& Teplovs, 1999, p. 233).

I denne amerikanske undersøgelse er den gennemsnitlige trådlængde på knap 3 meddelelser varierende fra under 1 til godt 4 i de syv forskellige undersøgte uddannelsesforløb (Hewitt \& Teplovs, 1999, p. 233). Nogle tråde er oprettet med blot en enkelt meddelelse, der efterfølgende er slettet. Derfor er nogle tråde simpelthen tomme.

Den computerkonferencekommunikation, jeg analyserede i mit ph.d.-projekt, bestod af 1.401 computerkonferencemeddelelser genereret af et hold studerende i løbet af deres halvandetårige teknologistøttede uddannelse til Voksenundervisere. I denne empiri genfandt jeg dette typiske mønster, nemlig at 123 tråde (svarende til 41\% af det samlede antal tråde) kun bestod af én meddelelse (Rattleff, 2001, p. 165). I gennemsnit bestod et emne i denne empiri af knap 5 meddelelser (ibid).

Sammenfattende er det således bemærkelsesværdigt, at de MIL-studerendes VU-kommunikation følger et andet mønster - med få, lange, faglige tråde - end det traditionelle - med mange, korte, tråde.

\section{Operationalisering af forhandlingsbegrebet}

Inspireret af den amerikanske psykolog og psykoanalytiker George A. Kelly (Kelly, 1955, 1963) Personal Constructs Psychology (PCP) definerer Thomas \& Harri-Augstein (1985, p. xxiv) som nævnt læring som: "The construction, reconstruction, negotiation and exchange of personally significant, relevant and viable meaning.”

Med baggrund i Thomas \& Harri-Augsteins definition antages forhandling således i denne sammenhæng at etableres som eksplicitering, udveksling og forhandling af mening.

I den empiriske undersøgelse af forhandling bliver det således interessant at kvantificere, hvornår de studerende ekspliciterer, udveksler og forhandler mening. 'Personlig betydningsfuld, relevant og brugbar mening’ sættes i denne (uddannelses-)sammenhæng lig med tekst i computerkonferencemeddelelser med faglig studierelateret information (jf. definitionen i Rattleff, 2001, p. 121ff). Jf. definitionen i Rattleff (2001, p. 155ff) operationaliseres eksplicitering, udveksling og forhandling videre på følgende vis:

Der er tale om eksplicitering af mening, når en studerende skriver og poster en computerkonferencemeddelelse med fagligt studierelateret information. 
Der er tale om en udveksling, hvis mindst to studerende ekspliciterer meninger om det samme emne, hvilket vil sige i forlængelse af hinandens computerkonferencemeddelelser i samme tråd med anvendelse af computerkonferencesystemets Reply-funktion ${ }^{5}$.

Der er tale om en forhandling, hvis minimum én studerende i forlængelse af denne udveksling med anvendelse af 'Reply-funktionen' anfcegter den ene eller den anden af de to forudgående ekspliciteringer ${ }^{6}$.

Forhandling indebærer således en skepsis, en anfægtelse, uenighed, men en forhandling kan også komme i stand ved, at en person tilkendegiver, at vedkommende affødt af udvekslingerne af synspunkter har konstrueret en ny mening.

I det elektroniske spørgeskema, der er anvendt som et af flere dataindsamlingsredskaber, er forhandling præciseret på følgende vis: ”Når ordet forhandling indgår i de følgende spørgsmål, menes faglig uenighed, hvor der udveksles synspunkter om et fagligt emne, et eksempel, en teori, en case eller en problemstilling."

\section{Spørgeskema om studerendes anvendelse af forhandling i deres individuelle læreprocesser}

Til at undersøge de studerendes syn på og brug af VU-kommunikationen udformede jeg et elektronisk spørgeskema med i alt 85 spørgsmål angående de studerendes syn på og brug af VU-kommunikationen. Det elektroniske spørgeskema opnåede med 21 ud af 34 mulige besvarelser en svarprocent på 62 .

Indledningsvis præciserede jeg, hvad spørgeskemaet vedrørte med følgende tekst: "Spørgsmålene i dette spørgeskema drejer sig om dit syn på og brug af de 300 VU-meddelelser, der i perioden fra den 14. september til den 4. oktober 2005 blev postet i konferencen "MIL2(m3)Diskus_periode1", som blev oprettet til den første online diskussionsperiode på MILs modul 3 om ”IKT og organisatoriske læreprocesser” i efteråret 2005”.

Efter nogle indledende spørgsmål (baggrundsvariable) spurgte jeg derefter til brugen af VUkommunikationen med henblik på, om de studerende skimmede, nærlæste, genlæste og/eller udskrev VU-meddelelser. Desuden spurgte jeg om, hvorvidt og hvorfor de studerende skrev og postede VU-meddelelser samt hvordan de studerende vurderede VU-konferencesystemets håndtering af forhandling. Afslutningsvis bad jeg de studerende vurdere, hvilken betydning de forskellige VU-aktiviteter (skimme, genlæse, nærlæse henholdsvis skrive og poste meddelelser) havde for de studerendes læring.

Det elektroniske spørgeskema giver med hensyn til spørgsmålene angående forhandling af faglige uenighed via konferencesystemet respondenterne mulighed for at svare på følgende vis (for så vidt angår spørgsmålet i nedenstående figur beder jeg i spørgeskemaet de studerende angive ved afkrydsning, i hvilken grad de er enige i følgende synspunkter):

Jeg skrev og postede meddelelser, fordi jeg var enig i hele eller dele af indholdet i meddelelsen, jeg svarede på

Figur 1. Benævnte og ubenævnte svarkategorier i det elektroniske spørgeskema. 
Mellem de benævnte yderkategorier er det således muligt for de studerende at sætte kryds i yderligere fire ubencevnte felter.

\section{Fremlæggelse og diskussion af udvalgte resultater}

Dette er en betinget analyse, idet jeg udelukkende præsenterer og diskuterer udvalgte resultater, udvalgt ud fra relevanskriteriet om, at resultaterne skal vedrøre forhandling og betydningen af forhandlingerne for de studerendes læring.

Ved fremlæggelse af de udvalgte, empiriske resultater er data opgjort summarisk på følgende vis: De to yderkategorier, hvoraf den ene er benævnt enten "Helt enig”, "I høj grad en fordel”, "Slet ikke en ulempe” henholdsvis "Mere betydning”, er slået sammen og omtales som "Enig”, "Fordel”, ”Ikke en ulempe" og "Betydning”. Tilsvarende er de to andre yderkategorier, hvoraf den yderste er benævnt "Helt uenig”, ”Slet ikke en fordel”, ”I høj grad en ulempe” henholdsvis "Mindre betydning”, slået sammen og benævnes "Uenig”, ”Ikke en fordel”, ”Ulempe” henholdsvis ”Ingen betydning” - jf. følgende eksempel:

\begin{tabular}{|c|c|c|c|c|c|}
\hline $\begin{array}{c}\text { Helt enig } \\
\square\end{array}$ & $\square$ & $\square$ & $\square$ & $\square$ & Helt uenig \\
\hline
\end{tabular}

Figur 2. Svarkategorierne i de oprindelige spørgsmål i det elektroniske spørgeskema.

\begin{tabular}{|c|c|cc|}
\hline Enig & Ikke klar stillingtagen & \multicolumn{2}{c|}{ Uenig } \\
$\square$ & $\square$ & $\square$ & $\square$ \\
\hline
\end{tabular}

Figur 3. Svarkategorier ved prcesentation af datamaterialet.

Den summariske kategori 'Enig' dækker således over den svarmulighed, der er benævnt 'Helt enig' og den svarmulighed, der muligvis kunne benævnes 'Delvis enig'. Tilsvarende dækker den summariske kategori 'Uenig' over den svarmulighed, der er benævnt 'Helt uenig' og den svarmulighed, der muligvis kunne benævnes 'Delvis uenig'. De summariske kategorier 'Enig' og 'Uenig' kunne derfor også benævnes 'Helt eller delvis enig' henholdsvis 'Helt eller delvis uenig'. For overskuelighedens skyld benævner jeg dog de summariske kategorier 'Enig' henholdsvis 'Uenig'.

\section{Om at nærlæse og genlæse computerkonferencemeddelelser}

I det elektroniske spørgeskema skelnes mellem at åbne, at skimme, at nær- og genlæse computerkonferencemeddelelser. Denne skelnen er teoretisk begrundet med, at den omhu, med hvilken en tekst (dvs. den genererede computerkonferencekommunikation med studierelateret faglig information) læses, har betydning for den studerendes læring.

Desuden antages det, at det at genlæse og derved blive mindet om indholdet af computerkonferencemeddelelserne styrker grundfrestningen af det lærte.

I spørgeskemaundersøgelsen spurgte jeg derfor de studerende, hvorfor de skimmede, nærlæste og/eller genlæste VU-meddelelser. Svarene viser, at hele $91 \%$ af de studerende var enige i, at de ncerlaste VU-meddelelser, fordi de ville skrive og poste svar på meddelelsen, mens de resterende $9 \%$ var uenige heri.

Dette var dog ikke den eneste grund til at nærlæse meddelelser; Mellem 81\% og 91\% angav, at de var enige i, at de nærlæste VU-meddelelser, fordi disse var relevante, anvendelige og/eller interessante og/eller spændende. 
I modsætning hertil, angav 70\% at de var enige i, at de skimmede VU-meddelelser, fordi indholdet var irrelevant, mens 50\% angav, at indholdet ikke fængede eller at meddelelsen var (for) lang, mens $50 \%$ var enige i, at de skimmede VU-meddelelser, fordi meddelelsen var henvendt til en anden.

Med hensyn til de studerendes bevæggrunde for at genlæse meddelelser, så angav de studerende, der besvarede dette spørgsmål, samstemmende, at de gjorde det, fordi de ville skrive og poste et svar på meddelelsen. Desuden angav 82\%, at de nærlæste en meddelelse, fordi indholdet var relevant eller anvendeligt.

Disse besvarelser er i udmærket overensstemmelse med argumentationen hos forskellige læringsteoretikere, der argumenterer for, at inddragelse af erfaringen, behov, relevans og umiddelbar anvendelighed er afgørende for voksnes læring. Cook (1995, p. 36) fremfører således eksempelvis, at brugen af computerkonferencer og muligheden for self-directed learning med afsæt i egne behov netop er i overensstemmelse med Stephen Brookfields og Malcolm Knowles forestillinger om det særegne ved (grundfæstning af) voksnes læring.

Som svar på det åbne spørgsmål om, hvorfor studerende valgte at skimme meddelelser, svarede respondenterne (det følgende er citater fra den elektroniske spørgeskemaundersøgelse):

- "Hvis emnet var/er marginalt i forhold til mit behov."

- "I større diskussions-fora skimmer jeg først overskrifter, herefter indholdet i indlægget for at afgøre, om det f.eks. er interessant eller er relevant for mig."

- "Bagefter (eller undervejs) vender jeg tilbage det det, der fængede.”

\section{Om at skrive og poste computerkonferencemeddelelser}

Det står således klart, at de studerende nær- og især genlæser VU-meddelelser, når de påtænker at skrive og poste et svar. I forlængelse af dette bliver spørgsmålet da, hvad der motiverer de studerende til netop at skrive og poste VU-meddelelser?

I det elektroniske spørgeskema har jeg derfor spurgt de studerende om, hvorfor de skrev og postede meddelelser i løbet af den første online diskussionsperiode. De studerende blev bedt om at angive, hvor enige de var i følgende synspunkter (antallet af respondenter på det pågældende spørgsmål er 21, det absolutte antal besvarelser er angivet i parentes):

\begin{tabular}{|c|c|c|c|}
\hline Synspunkt & Enig & Uenig & $\begin{array}{l}\text { Ikke klar } \\
\text { stillingtagen }\end{array}$ \\
\hline $\begin{array}{l}\text { Jeg skrev og postede meddelelser, fordi jeg var enig i hele eller dele af indholdet } \\
\text { i meddelelsen, jeg svarede på }\end{array}$ & $52 \%(11)$ & 0 & $48 \%(10)$ \\
\hline $\begin{array}{l}\text { Jeg skrev og postede meddelelser, fordi jeg gerne ville komme med en tilføjelse } \\
\text { til indholdet i meddelelsen, jeg svarede på }\end{array}$ & $76 \%(16)$ & $5 \%(1)$ & $19 \%(4)$ \\
\hline $\begin{array}{l}\text { Jeg skrev og postede meddelelser, fordi jeg gerne ville nuancere indholdet i } \\
\text { meddelelsen, jeg svarede på }\end{array}$ & $52 \%(11)$ & $10 \%(2)$ & $38 \%(8)$ \\
\hline $\begin{array}{l}\text { Jeg skrev og postede meddelelser, fordi jeg var uenig i hele eller dele af } \\
\text { indholdet i den meddelelse, jeg svarede på, og gerne ville komme med et } \\
\text { kontraindlceg }\end{array}$ & $67 \%(14)$ & 0 & $33 \%(7)$ \\
\hline $\begin{array}{l}\text { Jeg skrev og postede meddelelser, fordi hele eller dele af indholdet i } \\
\text { meddelelsen, jeg svarede på, var svært at forstå - og jeg gerne ville have uddybet } \\
\text { og /eller forklaret indholdet yderligere }\end{array}$ & $10 \%(2)$ & $47 \%(10)$ & $43 \%(9)$ \\
\hline $\begin{array}{l}\text { Jeg skrev og postede meddelelser, fordi jeg i forlængelse af indholdet i den } \\
\text { meddelelse, jeg svarede på, gerne ville have et konkret eksempel }\end{array}$ & $5 \%(1)$ & $81 \%(11)$ & $14 \%(3)$ \\
\hline $\begin{array}{l}\text { Jeg skrev og postede meddelelser, fordi det var et beståelseskrav på modul 3, at } \\
\text { man som studerende deltager aktivt i VU-kommunikationen }\end{array}$ & $61 \%(13)$ & $10 \%(2)$ & $29 \%(6)$ \\
\hline
\end{tabular}

Tabel 1. De studerendes bevæeggrund for at skrive og poste VU-meddelelser. 
Det fremgår af tabellen, at $76 \%$ af respondenterne skriver og poster meddelelser, fordi de gerne vil komme med en tilføjelse, $67 \%$ fordi de er uenige, og $52 \%$ fordi de er enige eller vil nuancere et tidligere fremsat synspunkt. Desuden angiver 61\%, at de skriver og poster meddelelser, fordi det er et beståelseskrav.

En studerende skrev (som svar på det åbne spørgsmål om, hvorfor de studerende skrev og postede meddelelser): "Selvfølgelig tæller man, når der er krav om et vist antal indlæg, men jeg oplevede på samme tid - måske for første gang i de virtuelle diskussioner - at diskussionsperioden virkelig gav nye input og nye vinkler på emnet/materialet.”

\section{Om forhandling af faglig uenighed}

Fremkomsten af internettet har som tidligere nævnt ført til, at det i litteraturen antages, at der er mange - i hvert fald principielle - fordele ved at teknologistøtte undervisning, idet denne teknologistøtte som nævnt antages at fremme de studerendes læring.

Uden at jeg i denne sammenhæng skal komme nærmere ind på disse fordele, fremhæves ”[...] fleksibiliteten ved de netbaserede fjernstudier igen og igen som en fordel set fra de studerendes synsvinkel.” (Rattleff, 2002, p. 96, gengivet uden noter)

Desuden skal det nævnes, at litteraturen, som jeg skal komme nærmere ind på i næste afsnit, er meget optaget af, at kommunikation, der udbredes via computerkonferencer, er permanent og "[...] danner et rum af og om gruppen. Man kan vende tilbage til tidligere diskussioner, printe 'hele rullen ud' og få en fornemmelse af forløbet i en diskussion eller blive opdateret på et emne og re-introducere emner, som kommunikationen har forladt, men gemt.” (Rattleff, 2000, p. 218)

Når jeg særligt fremhæver disse to, formodede, fordele skyldes det, at de studerende i deres besvarelser af det elektroniske spørgeskema netop fremhæver det fleksible og det fastholdte som styrker ved, at faglige forhandlinger foregår asynkront via VU. Hele 85\% af de studerende betragter det således som en fordel ved skriftlige asynkrone forhandlinger, at de har mulighed for at læse andres VU-meddelelser - på det tidspunkt og det sted, der passer dem, og at kommunikationens fastholdte natur giver mulighed for at vende tilbage og nær- og/eller genlæse og/eller printe og/eller genbruge kommunikationen.

I det pilotinterview, jeg gennemførte med to studerende forud for udformningen af det elektroniske spørgeskema, fremførte den ene studerende, at "faglig uenighed styrker læringsindsatsen", fordi man er "nødt til at kunne argumentere - viden står der jo til evig tid - for at kunne gå ind i diskussionen.” Og videre at: ”Det er deri - for mit vedkommende - at læringen den ligger, der er meget refleksion i den måde at arbejde på.”

Som svar på det åbne spørgsmål om fordelene ved asynkron forhandling skriver en studerende: ”Refleksionen!” Netop refleksion fremhæves da også som nævnt som en formodet fordel ved den skriftlige asynkrone forhandling: "The asynchronicity of online interactions allows participant time to reflect on a topic before commenting or carrying out online tasks." (Harasim et al., 1995, p. 27). Tilsvarende argumenter findes i anden litteratur (jf. eksempelvis fremstillingen i Newman et al., 1995) - om end det tilsyneladende er vanskeligt at fremvise empiriske belæg for den formodede sammenhæng mellem asynkrone forhandlinger og refleksion (Harrington \& Hathaway, 1994; Rattleff, 2005c; Seale \& Cann, 2000) 
Som Robin Mason bemærkede tilbage i 1994, er der - hver gang man kan forestille sig en fordel ved computerkonferencekommunikationen - typisk samtidig ulemper forbundet med denne form for kommunikation:

Most of the advantages of computer conferencing have disadvantages bound up intimately with them. For example, the much vaunted time for reflection produces no pressure to respond and the silence in many conferences is deafening! On the other hand, the equal opportunity for all to express their opinions can lead to chaos and an overwhelming number of messages. While the textual nature of the medium has educational advantages, writing takes longer to produce and to read than speech. All in all, most people find conferencing a time-consuming activity. (Mason, 1994, p. 59)

Som ulemper ved computerkonferencens håndtering af skriftlig, asynkron forhandling angiver de masterstuderende, at det især er en ulempe, at det kan være svært at danne sig et overblik over kommunikationen og de mange indlæg. Dette kan ses som bagsiden af fordelen ved, at enhver kan begynde en tråd om hvad som helst ud fra egen interesse og komme med kommentarer til hvad som helst. Hele 60\% af de studerende angiver det desuden som en ulempe, at man kan slette VU-meddelelser, og 50\% fremfører, at det er en ulempe, at det kan være svært at følge med og nå at læse alle relevante indlæg. Som Mason fremfører, er det en tidskrævende aktivitet at producere og læse skrevne tekster.

Som svar på det åbne spørgsmål om ulemper ved den asynkrone kommunikation skriver en studerende: "Man mister nemt den hurtige meningsudveksling, som kan være uhyre produktiv. Man kommer måske hurtigere (og længere?) ind til benet, hvad én nuance angår, i en diskussion f2f. Men til gengæld får man en lidt tungere udveksling [rent] fagligt [...]”

\section{Om sammenhæng mellem aktiviteter og egen læring}

I dette afsnit sammenligner jeg MIL-studerendes syn på VU-kommunikationen med finanselevers syn på den finansielle sektors internetudbredte uddannelsesportal, FOKUS (Finanssektorens Online Konference og UddannelsesSystem).

I projektet Fokus på FOKUS - Nye veje i teknologistøttet, arbejdsmarkedsrettet laring. En komparativ og udviklingsorienteret empirisk undersøgelse af arbejdsmarkedsrettet laring ved anvendelse af finanssektorens uddannelsesportal, FOKUS har vi i projektgruppen efterprøvet to teser om, hvordan finanselevers brug af FOKUS styrker grundfcestningen af det lærte samt finanselevernes transfer af det lærte fra en uddannelses- til en arbejdspladssammenhæng ${ }^{7}$. Den overordnede hypotese var, at teknologiens (det vil sige computerkonferencens) mulighed for at fastholde kommunikation og fungere som videncenter er central. For at undersøge rigtigheden af denne grundlæggende formodning om, at FOKUS fungerer som et videncenter, spurgte vi i et elektronisk spørgeskema med i alt 143 spørgsmål en årgang finanseleverne (knap 550) om dette.

Af de 380 respondenter, der svarede på spørgsmålet om, hvorvidt de betragtede FOKUS som et videncenter, hvor man kan søge og finde information, angav 16\%, at de var (helt eller delvis) enige heri, mens 64\% svarede, at de var (helt eller delvis) uenige heri. De resterede 20\% svarede ’Både og' (Rattleff, 2005b, p. 68).

For så vidt angår finanselevernes syn på og brug af uddannelsesportalen FOKUS giver disse tal ikke umiddelbart belæg for at opretholde hypotesen om, at FOKUS bruges som et videncenter. Det skal dog understreges, at dette i høj grad hænger sammen med, hvordan 
FOKUS p.t. er udformet og ikke mindst bruges af finanselever og (måske især) lærerne (Rattleff, 2005b, p. 67).

I det elektroniske spørgeskema til de masterstuderende på Master i IKT og læring stillede jeg imidlertid det samme spørgsmål om de studerendes syn på VU som et videncenter. Og her er billedet et andet, idet 43\% af de studerende angav, at de var enige i, at de generelt bruger VU som et videncenter, hvor de søger og finder information og viden, mens en andel på $29 \%$ var uenige $\mathrm{i}$, at de generelt bruger VU som et videncenter. De resterende $28 \%$ tog ikke klart stilling til spørgsmålet.

Dette er grafisk fremstillet i de to lagkagediagrammer i figur 3 nedenfor.
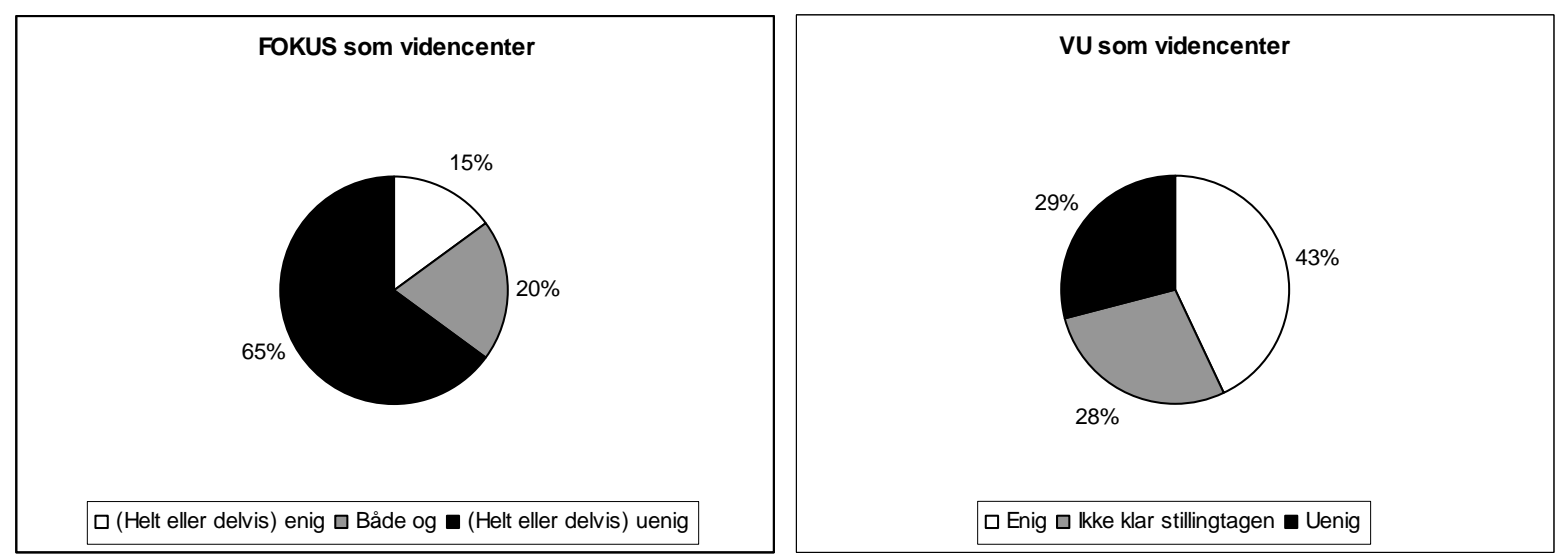

Figur 4. Brugen af FOKUS henholdsvis VU som videncenter.

Som tidligere nævnt viser der sig et andet mønster (færre, lange tråde) i de masterstuderendes computerkonferencekommunikation end det traditionelle mønster med flere, (meget) korte tråde. Og disse sammenlignende lagkagediagrammer viser tilsvarende et meget forskelligt syn på de respektive teknologier som videncentre.

I det elektroniske spørgeskema til de masterstuderende spurgte jeg, hvilken betydning de studerende vurderede, at de forskellige VU-aktiviteter (dvs. at skimme, at genlæse, at nærlæse henholdsvis at skrive og poste VU-meddelelser) havde for deres læring. Svarene fra de 20 respondenter, der besvarede disse spørgsmål, er gengivet i tabellen nedenfor (antal absolutte besvarelser i parentes).

\begin{tabular}{|l|r|r|r|}
\hline Synspunkt & Betydning & $\begin{array}{l}\text { Uden } \\
\text { betydning }\end{array}$ & $\begin{array}{l}\text { Ikke klar } \\
\text { stillingtagen }\end{array}$ \\
\hline Skimme VU-meddelelser & $30 \%(6)$ & $30 \%(6)$ & $40 \%(8)$ \\
\hline Genlæse VU-meddelelser & $40 \%(8)$ & $25 \%(5)$ & $35 \%(7)$ \\
\hline Ncerlese VU-meddelelser & $80 \%(17)$ & $10 \%(2)$ & $10 \%(2)$ \\
\hline Skrive og poste VU-meddelelser & $95 \%(19)$ & 0 & $5 \%(1)$ \\
\hline
\end{tabular}

Tabel 2. De studerendes vurdering af forskellige aktiviteters betydning for deres laring.

Af tabellen fremgår det, at hele 95\% af de studerende vurderer, at det at skrive og poste VUmeddelelser har betydning for deres læring. Mange (85\%) er desuden enige i, at det at nærlæse VU-meddelelser også har betydning.

Som tidligere vist er der den sammenhæng, at netop det at ville skrive og poste VU-meddelelser også fører til, at de studerende nær- og især genlæser VU-meddelelser. 


\section{Sammenfatning}

Disse, udvalgte resultater tyder sammenfattende på, at de studerende i høj grad betragter fleksibiliteten ved skriftlig, asynkron computerkonferencekommunikation tillige med den fastholdte natur af denne som fordele ved denne måde at tilrettelægge uddannelse og undervisning på. Dette er i udmærket overensstemmelse med litteraturens forestillinger.

Disse resultater er desuden i overensstemmelse med de læringsteoretiske argumenter om, at voksnes læring styrkes ved, at det, der kommunikeres om, skal være interessant, relevant og (umiddelbart) anvendeligt.

Det kan iagttages, at mønstret i de studerendes computerkonferencekommunikation i VU på MIL's modul 3 om "IKT og organisatoriske læreprocesser” er anderledes end det traditionelle mønster for computerkonferencekommunikation. De masterstuderende kommunikerer i færre, men længere, faglige tråde i modsætning til det traditionelle mønster med mange, meget korte tråde. I den første online diskussionsperiode på MIL's modul 3 om ”IKT og organisatoriske læreprocesser” kan det således iagttages, at de studerende i høj grad giver hinanden gensidig feedback - og at denne gensidige feedback (forhandlinger) af de studerende betragtes som betydningsfulde for de studerendes læring.

I relation til undersøgelsesspørgsmålet om, hvilken betydning disse forhandlinger har for den enkelte studerendes læreproces vurderer de studerende således, at det at skrive og poste VUmeddelelser har betydning for deres læring. De studerende begrunder deres skriven og posten af VU-meddelelser med ønsket om at komme med tilføjelser eller angive uenighed som vægtige bevæggrunde for at skrive og poste VU-meddelelser. Samtidig vurderer de studerende, at netop intentionen om at ville skrive og poste en VU-meddelelse som svar på en andens meddelelse i høj grad resulterer i, at den studerende nær- og eller genlæser VU-kommunikationen. Disse svar understøttes af de studerendes syn på VU som et videncenter, der er markant anderledes end eksempelvis finanselevernes syn på uddannelsesportalen FOKUS som videncenter.

I en artikel med titlen "CSCL - computer Supported Collaborative Learning. Projektpædagogiske læringsformer i virtuelle omgivelser” skriver forskningsprofessor Lone DirckinckHolmfeld tilsvarende om MIL-studerendes forhandling af mening: ”Et konferencesystem giver nogle bestemte betingelser for i fællesskab at konstruere mening [...] Vi påstår endvidere, at der er tale om et potentielt refleksivt læringsrum [...] Netop forhandling af mening kræver mulighed for koordination af perspektiver, og dette kan være meget vanskeligt [...] Det er meget vigtigt, at man i tilrettelæggelsen af læringsmiljøet tager hensyn til styrkerne og svaghederne ved de enkelte medier [...]” (Dirckinck-Holmfeld, 2002, p. 60)

I forlængelse af disse betragtninger skal det afslutningsvis bemærkes, at en del af forklaringen på, at mønstret i de MIL-studerendes kommunikation adskiller sig fra det traditionelle kommunikationsmønster i kommunikation i computerkonferencer muligvis skal søges i det forhold, at MIL er en masteruddannelse, der netop har IKT og læring som sit genstandsfelt. De MIL-studerende er derfor i udgangspunktet pr. definition interesseret i og optaget af netop forholdet mellem læring og anvendelse af forskellige teknologier, herunder computerkonferencer. 


\section{Noter}

$1 \quad$ Forhandling (i ental) anvendes som term for fænomenet på et generelt niveau, mens forhandlinger (i flertal) anvendes for de konkrete forhandlinger, de studerende kan iagttages at have i computerkonferencer.

2 Der findes forskellige definitioner af computerkonferencer. Lancaster et al. definerer computerkonferencer som: "[...A] computer-based method for communicating and discussing course-related issues outside the classroom. Conferencing provides an asynchronous learning experience that will enhance more traditional activities. Posting to an interactive, computer based "bulletin board" gives students and faculty opportunities to interact after class has ended.” (Lancaster \& Stokes, 1999, p. 2)

3 Distinktionen mellem 1) studierelateret faglige information, 2) studierelateret praktisk-organisatoriske information og 3) ikke-studierelaterede, personlige information er nærmere udfoldet i Rattleff (2001, pp. 121-130).

$4 \quad$ I denne artikel anvendes betegnelserne MIL-studerende, masterstuderende, studerende (og til dels også) respondenter (mere eller mindre) synonymt.

5 Det er naturligvis muligt, at 'Reply-funktionen' anvendes, selvom dette ikke er tiltænkt, og der således (reelt) ikke er tale om udveksling af meninger. Der kan således være et validitetsproblem i denne sammenhæng.

6 Den anfægtende studerende kan være den ene af de to studerende, der udvekslede meninger, eller det kan være en tredje studerende.

7 Forskningsprojektet - herunder det elektroniske spørgeskema og spørgeskemaundersøgelse, der opnåede en svarprocent på 82 - er nærmere beskrevet i flere fremstillinger (se eksempelvis Rattleff, 2005a, 2005b).

\section{Referencer}

Benseman, J. (1999). Superhighway or Dirt Road? Moving Beyond the Hype with Computer Mediated Communication. Australian Journal of Adult and Community Education, Vol 39(No 3), 143-153.

Bygholm, A., \& Dirckinck-Holmfeld, L. (1997). Pædagogik i det virtuelle læremiljø - metodiske overvejelser. In O. Danielsen (Ed.), Lering og multimedier (pp. 63-89). Aalborg: Aalborg Universitets Forlag.

Cook, D. L. (1995). Community and Computer-Generated Distance Learning Environments. In M. H. Rossman \& M. E. Rossman (Eds.), Facilitating Distance Education. San Francisco: Jossey-Bass Publishers.

Dirckinck-Holmfeld, L. (2002): CSCL - Computer Supported Collaborative Learning. In: Uddannelse, læering og IT - 26 forskere og praktikere gør status på området. København: Undervisningsministeriet, Uddannelsesstyrelsen.

Ellström, P.-E. (1997). Kompetens, utbildning och lärande i arbejdslivet. Problem, begrepp och teoretiska perspektiv. Stockholm: Norstedts Juridik AB.

Grue-Sørensen, K. (1974). Almen pædagogik. En håndbog i de pæedagogiske grundbegreber. København: Gjellerup.

Gunawardena, C. N., Lowe, C. A., \& Anderson, T. (1998). Transcript Analysis of Computer-Mediated Conferences as a Tool for Testing Constructivist and Social-Constructivist Learning Theories. Paper presented at the Distance Learning. Proceedings of the Annual Conference on Distance Teaching \& Learning, 14th, Madison, WI, August 5-7, 1998.

Harasim, L., Hiltz, S. R., Teles, L., \& Turoff, M. (1995). Learning Networks. A Field Guide to Teaching and Learning Online. Massachusetts: Massachusetts Institute of Technology.

Harrington, H. L., \& Hathaway, R. S. (1994). Computer Conferencing, Critical Reflection, and Teacher Development. Teaching \& Teacher Education, 10(5), 543-554.

Hewitt, J., \& Teplovs, C. (1999). An Analysis of Growth Patterns in Computer Conferencing Threads. Paper presented at the Computer Support for Collaborative Learning. Designing New Media for a New Millennium: Collaborative Technology for Learning, Education, and Training, December 12-15, 1999, Palo Alto, California. 
Kelly, G. A. (1955). The Psychology of Personal Constructs Vol 1 \& 2 (Volume one: Theory and personality, Volume two: Clinical diagnosis and psychotherapy). New York: Routledge.

Kelly, G. A. (1963). A Theory of Personality. The Psychology of Personal Constructs. New York, London: W W Norton Company.

Lancaster, K., \& Stokes, J. (1999). Electronic Conferencing in Education: An Example from Social Work. from http://www.mtsu.edu/ itconf/proceed99/lancaster.htm

Luhmann, N. (1988). Erkendelse som konstruktion (B. Moss-Petersen, Trans.). In M. Hermansen (Ed.), Fra leringens horisont (pp. 163-183). Århus: Klim.

Mason, R. (1994). Using Communications Media in Open and Flexible Learning. London: Kogan Page Limited.

Newman, D., Webb, B., \& Cochrane, C. (1995). A Content Analysis Method to Measure Critical Thinking in Face-to-face and Computer Supported Group Learning. Interpersonal Computing and Technology: An Electronic Journal for the 21st Century, ISSN: 1064-4326 http://jan.ucc.nau.edu/ ipctj/1995/n2/newman.txt., 3(2), 56-77.

Rattleff, P. (2000). Elektroniske hypertekster som studiemateriale - hvorfor printer studerende teksten ud? In M. Hermansen, K. Haastrup \& H. S. Olesen (Eds.), Tema Lceringslandskaber - artikler om lcering og fagdidaktik (pp. 209-221). København: Danmarks Lærerhøjskole.

Rattleff, P. (2001). Studiegruppers faglige diskussioner i computerkonferencer i et fjernstudium. Ph.d.afhandling. København: Danmarks Pædagogiske Universitet.

Rattleff, P. (2002). Fleksible, netbaserede fjernstudier. In Undervisningsministeriet (Ed.), IT, undervisning og lering - 26 forskere og praktikere gør status (pp. 97-105). København: Undervisningsministeriet (www.uvm.dk).

Rattleff, P. (2003). Egner computerkonferencekommunikation sig til forhandling? In H. Mathiasen (Ed.), IT og lceringsperspektiver (pp. 38-56). København: Alinea.

Rattleff, P. (2005a). Hvor tit slår De Deres kone? - om formulering af spørgsmål i en surveyundersøgelse. In I. M. Bryderup (Ed.), Social ulighed - et festskrift i anledning af professor Erik Jørgen Hansens 70 års fødselsdag. København: Danmarks Pædagogiske Universitet.

Rattleff, P. (2005b). Hvordan understøtter brug af informations- og kommunikationsteknologi finanselevers læring? In M. Buhl, B. H. Sørensen \& B. Meyer (Eds.), Medier og it - lceringspotentialer. København: Danmarks Pædagogiske Universitets forlag.

Rattleff, P. (2005c). What is This Thing Called Reflection? How We Think and What We Think About - A Generic Framework. In M. Buhl, B. H. Sørensen \& B. Meyer (Eds.), ICT and media - potentials for learning (pp. 171-189). København: Danmarks Pædagogiske Universitets forlag. Tilgængelig via www.forlag.dpu.dk under 'udgivelser 2006'.

Seale, J. K., \& Cann, A. J. (2000). Reflection on-line or off-line: the role of learning technologies in encouraging students to reflect. Computers \& Education, 34, 309-320.

Thomas, L. F., \& Harri-Augstein, E. S. (1985). Self-organised learning. Foundations of a conversational science for psychology (1. ed.). London: Routledge \& Kegan Paul. 